LAW RENCE LIVERMORE N A T IO N A L LABORATORY

2007 Inventory of

Radiochemistry Detector

Elements and Compounds

J. Kenneally, K. Roberts

April 10, 2007 
This document was prepared as an account of work sponsored by an agency of the United States Government. Neither the United States Government nor the University of California nor any of their employees, makes any warranty, express or implied, or assumes any legal liability or responsibility for the accuracy, completeness, or usefulness of any information, apparatus, product, or process disclosed, or represents that its use would not infringe privately owned rights. Reference herein to any specific commercial product, process, or service by trade name, trademark, manufacturer, or otherwise, does not necessarily constitute or imply its endorsement, recommendation, or favoring by the United States Government or the University of California. The views and opinions of authors expressed herein do not necessarily state or reflect those of the United States Government or the University of California, and shall not be used for advertising or product endorsement purposes.

This work was performed under the auspices of the U.S. Department of Energy by University of California, Lawrence Livermore National Laboratory under Contract W-7405-Eng-48. 


\section{Inventory of Radiochemistry Detector Elements and Compounds}

\section{Kevin Roberts and Jacqueline Kenneally}

30 March 2007

Since the last report, there have been no material changes in the detector element inventories in buildings 151 and 332 at LLNL. Stable element inventories in building 151 have remained stable since the inventory in September 2005. For the first time in many years, Stockpile Radiochemistry personnel viewed radioactive tracer materials that reside in building 332. A list of LLNL tracers and locations are available under separate cover.

Despite the recent NNSA agreement to retain $2.8 \mathrm{~kg}$ of ${ }^{233} \mathrm{U}$ for programmatic purposes, we have yet to identify a location that is appropriate and will accept the material. A recent visit to the Oak Ridge National Laboratory (ORNL) in September 2006 revealed nearly $190 \mathrm{~kg}$ of material with very high ${ }^{233} \mathrm{U}$ content scheduled for down-blending in various chemical and isotopic forms. The chemical form, isotopic and chemical purities of this material were such that roughly $150 \mathrm{~kg}$ of the material was of comparable composition to the desired tracer package material and would be acceptable for use in an underground test, should the US even conduct such a test. Efforts continue to remove 2.8 $\mathrm{kg}$ of material from the down-blend cue and reserve it for the Test Readiness mission. 